\title{
The Rise of Developing Asia and the
}

\section{New Economic Order}

\section{by}

\section{Dale W. Jorgenson ${ }^{1}$ and Khuong M. $\mathrm{Vu}^{23}$}

Abstract: This paper identifies emerging trends in the world economy during the next decade. The first is that China will overtake the U.S. in terms of gross domestic product (GDP), ending more than a century of U.S. leadership as the world's largest economy. The second is that Developing Asia, excluding Japan, will overtake the G7, a group of the seven largest industrialized economies established in 1975-6. Finally, India will overtake Japan, Russia will overtake Germany, and Brazil will overtake the U.K., leading to a New World Economic Order: China, the U.S., India, Japan, Russia, Germany, and Brazil.

Key words: growth, information technology, investment, productivity.

JEL classification: $\mathrm{O} 47$.

\section{Introduction.}

As the world economy recovers from the Great Recession of 2007-2009, the revival of growth in the U.S., Canada, Europe, Japan, and other industrialized countries has been slow and protracted. International imbalances and fiscal consolidations have become more pressing, both economically and politically. ${ }^{4}$ A successful recovery will require skillful withdrawal

\footnotetext{
${ }^{1}$ Samuel W. Morris University Professor, Harvard University.

2 Assistant Professor of Public Policy, Lee Kuan Yew School of Public Policy, National University of Singapore.

${ }^{3}$ We are grateful to Jon Samuels of Johns Hopkins University and Hieu Nguyen of the National University of Singapore for excellent research assistance and very helpful comments.

${ }^{4}$ See IMF, World Economic Outlook, April 2011.
} 
from policies adopted to cope with the downturn. Could a new and perhaps unexpected shock interrupt the recovery?

An obvious threat to the restoration of economic growth is the continued worsening of the sovereign debt crisis in Europe and the inability of international institutions to cope with a fiscal and financial crisis in large countries like Spain and Italy. Among the emerging economies the challenges are different, but equally daunting. Can China successfully handle the inflationary pressures following the vast expansion of lending in response to the financial crisis? Will India undertake a fiscal consolidation without threatening rapid growth, now exceeding the growth of China?

In this paper we shift attention from threats to the short-term growth of the world economy, as formidable as these may be, to growth potential over the next decade. The fundamentals for the world economy are strong. Moreover, it is time to recognize the emerging trends that have developed since the watershed reforms of China and India more than two decades ago. A massive reconfiguration of the world economy is gradually unfolding and will be completed in the next ten years.

We focus on the Rise of Developing Asia, where this refers to sixteen economies of East and South Asia, excluding Japan. These include China and India, the two largest countries of the world in population and two of the most rapidly growing economies. Developing Asia also includes the Newly Industrialized Economies of Asia - Hong Kong, Korea, Singapore, and Taiwan. Developing Asia has emerged from the Great Recession of 2007-2009 with growth trends largely intact. This reflects "lessons learned" during the Asian Crisis of the 1990's and the deployment of substantial international reserves as buffers against the recessionary shock. 
The first of the major trends in the world economy to be realized within the next decade is that China will overtake the U.S. One of the most heralded economic developments of 2010 was that China overtook Japan as the world's second largest economy. In terms of purchasing power parities this was old news. According to the World Bank scorecard, China overtook Japan more than five years ago. ${ }^{5}$ What was the hullaballoo? In 2010 China overtook Japan in terms of exchange rates rather than purchasing power parities.

Whether international comparisons are based on purchasing power parities or exchange rates, we can agree that China is No. 2. However, China is growing much faster than the U.S., the world's No. 1 economy for more than a century, according to the authoritative estimates of the late Angus Maddison. ${ }^{6}$ When will China become No. 1 ? The International Monetary Fund's World Economic Outlook for April 2011 calls for parity between the two economies in 2016. Our conclusion is that the most likely date for China to become No. 1 in terms of purchasing power parities as defined by the World Bank is 2018.

An exclusive focus on China-U.S. comparisons is unwarranted, even though these two economies will comprise more than a third of the world economy in 2020 . What other changes can we anticipate? The second major trend is that Developing Asia will overtake the $G 7$ in 2018. This trend will be largely driven by the rapid growth of China, but India will also make a significant contribution. Growth in the Asian Tigers - Hong Kong, Singapore, South Korea, and Taiwan - will continue to slow, but all except Hong Kong will grow more rapidly than the world economy. Indonesia's growth will equal that of the world economy.

The final trend is that India will overtake Japan, Russia will overtake Germany,

\footnotetext{
${ }^{5}$ See World Bank (2008).

${ }^{6}$ See Maddison (2006).
} 
and Brazil will overtake the U.K., leading to a New World Economic Order in 2020: China, the U.S., India, Japan, Russia, Germany, and Brazil. The G7 was established as a group of the six leading advanced economies in 1975 and Canada was added in 1976. The rise of Developing Asia and other emerging and transition economies like Russia and Brazil is already anticipated in the shift from the G7 to the G20 for international policy deliberations.

How do we arrive at these conclusions? We first analyze the sources of economic growth for the world economy, seven regions, and fourteen major economies during four periods - 1990-1995, 1995-2000, 2000-2005 and 2005-2009. We then project the potential growth rates of labor productivity and GDP for 122 economies over the ten-year period 20102020. Relative to historical growth for 1990-2009, we project lower growth rates for the world economy and the major regions.

In a previous paper ${ }^{7}$ we have presented measures of real output and input, as well as productivity, for 122 countries for the period 1990-2008. Our concept of real output employs measures of real GDP presented in the World Bank's International Comparison Program (ICP). We have developed measures of real input based on the production account proposed by Jorgenson and Landefeld (2006). Productivity is the ratio of real output to real input. These estimates are essential for projecting the potential growth of the U.S. and the world economy, as demonstrated by Jorgenson, Ho, and Stiroh (2008).

As recently as 2000 the G7 economies accounted for more than half of world GDP, while Developing Asia accounted for just under twenty percent. The rise of Developing Asia has been unrelenting and the corresponding figures for 2009 were 41.5 for the $\mathrm{G} 7$ and 27.5 for Developing Asia. Our projections indicate a change of leadership to Developing Asia in 2018.

\footnotetext{
${ }^{7}$ See Jorgenson and $\mathrm{Vu}$ (2010). Our measures of productivity are also consistent with Paul Schreyer's (2001) OECD Productivity Manual.
} 
Noting that Japan belongs to the G7 and not to Developing Asia, the change to Asia will occur even earlier.

In Section 2 we present our measures of output, input, and productivity. We document the resurgence of economic growth in the world economy after 1995 and the deceleration of growth after 2005 in Section 3. In Section 4 we allocate economic growth to the contributions of capital and labor inputs and productivity and show that input growth greatly predominates. We present relative levels of output and input per capita and productivity for 1990, 1995, 2000, 2005, and 2009 in Section 5. Section 6 describes the uncertainties about the future growth of the world economy and Section 7 gives our projections of potential growth for 2010-2020. Section 8 concludes the paper.

\section{Growth Accounting.}

The major challenge in implementing a consistent and integrated production account like that of Jorgenson and Landefeld (2006) is the construction of a measure of real input. The 1993 System of National Accounts (SNA) and BLS (1993) have provided measures of the price and quantity of labor services. These can be combined with the price and quantity of capital services introduced by BLS (1983) to generate price and quantity indexes of real input, as well as multifactor productivity. The primary obstacle to constructing of capital service measures is the lack of market rental data for different types of capital.

An alternative approach for measuring rental prices is to impute these prices from market transactions prices for assets, employing the user cost formula introduced by Jorgenson (1963). This requires estimates of depreciation and the rate of return, as well as asset prices. Measures of asset prices and depreciation, as well as investment and capital stocks, are presented in BEA's (2011) reproducible wealth accounts. BLS employs the 
imputed rental prices as weights for accumulated stocks of assets in generating price and quantity measures of capital services.

The most important innovation in the prototype system of national accounts developed by Jorgenson and Landefeld (2006) is to include prices and quantities of capital services for all productive assets in the U.S. economy. The incorporation of the price and quantity of capital services into the 2008 System of National Accounts (SNA) was approved by the United Nations Statistical Commission at its February-March 2007 meeting. The 2008 SNA was published in 2009. Paul Schreyer, head of national accounts at the OECD, has prepared an OECD Manual, Measuring Capital, also published in 2009.

In Chapter 20 of the 2008 SNA, "Capital Services and the National Accounts," estimates of capital services are described as follows: "By associating these estimates with the standard breakdown of value added, the contribution of (labor) and capital to production can be portrayed in a form ready for use in the analysis of productivity in a way entirely consistent with the accounts of the System." Our measures of capital and labor inputs are consistent with the new architecture for the U.S. national accounts, the 2008 SNA, Schreyer's (2001) OECD Productivity Manual, and his OECD Manual, Measuring Capital.

The output data for our growth accounts are compiled from World Development Indicators Online (2011). The input data are drawn from the following sources:

- The Conference Board Total Economy Database (TED) is our source for all input data for 24 OECD countries and data on employment and hours worked for all countries. ${ }^{8}$ This is

\footnotetext{
${ }^{8}$ See http://www.conference-board.org/economics/database.cfm. The OECD countries are: Canada, France, Germany, Italy, Japan, United Kingdom, United States, Australia, Austria, Belgium, Denmark, Finland, Greece, Iceland, Ireland, Israel, Luxembourg, Netherlands, New Zealand, Norway, Portugal, Spain, Sweden, Switzerland, and South Korea.
} 
also the source of labor quality growth for 103 countries; we use our own estimates, as described in Jorgenson and $\mathrm{Vu}$ (2010) for the remaining countries.

- The data on investment in information technology equipment and software are from Digital Planet reports published by the World Information Technology and Services Alliance (WITSA).

Our sample consists of 122 economies, which account for over 95 percent of world GDP and IT expenditures. For purposes of analysis, we divide the world economy into seven economic groups/regions:

1. G7 (seven largest industrialized economies): Canada, France, Germany, Italy, Japan, United Kingdom, and United States.

2. Non-G7 (17 non-G7 industrialized economies): Australia, Austria, Belgium, Denmark, Finland, Greece, Ireland, Iceland, Israel, Luxembourg, Netherlands, New Zealand, Norway, Portugal, Spain, Sweden, and Switzerland.

3. Developing Asia (16 economies):: Bangladesh, Cambodia, China, Hong Kong, India, Indonesia, Malaysia, Nepal, Pakistan, Philippines, Singapore, South Korea, Sri Lanka, Taiwan, Thailand, and Vietnam.

4. Latin America (20 economies): Argentina, Bolivia, Brazil, Chile, Colombia, Costa Rica, Dominican Republic, Ecuador, El Salvador, Guatemala, Honduras, Jamaica, Mexico, Nicaragua, Panama, Paraguay, Peru, Trinidad and Tobago, Uruguay, and Venezuela.

5. Eastern Europe and the former Soviet Union (22 economies): Albania, Armenia, Azerbaijan, Belarus, Bulgaria, Croatia, Czech Rep., Estonia, Georgia, Hungary, 
Kazakhstan, Kyrgyz Republic, Latvia, Lithuania, Poland, Romania, Russia, Slovakia, Slovenia, Tajikistan, Ukraine, and Uzbekistan.

6. Sub-Saharan Africa (29 economies): Benin, Botswana, Burkina Faso, Cameroon, Central African Rep., Chad, Congo Rep., Cote d'Ivoire, Ethiopia, Gabon, Ghana, Guinea, Kenya, Madagascar, Malawi, Mali, Mauritius, Mozambique, Namibia, Niger, Nigeria, Senegal, South Africa, Sudan, Swaziland, Tanzania, Togo, Uganda, and Zambia.

7. North Africa and Middle-East (11 economies): Algeria, Egypt, Iran, Jordan, Lebanon, Mauritania, Morocco, Syria, Tunisia, Turkey, and Yemen.

We also report results for seven leading countries of Developing Asia - China, Hong Kong, India, Indonesia, Singapore, South Korea, and Taiwan.

\section{World Economic Growth, 1990-2009.}

We have sub-divided the period 1990-2009 in 1995, 2000, and 2005 in order to capture the response of IT investment to the accelerated decline in IT prices in 1995 documented by Jorgenson (2001). The period 1995-2000 encompasses the IT-generated investment boom of the last half of the 1990's. The period 2000-2005 includes the dot-com crash of 2000, the shallow U.S. recession of 2001, and the slow recovery that followed. The period after 2005 is dominated by the economic and financial crisis of 2007-2009.

World economic growth has undergone a powerful revival since 1995. The GDP growth rate jumped more than a full percentage point from 2.20 percent during 1990-1995 to 3.37 percent in 1995-2000 and then to 3.71 percent in 2000-2005, as shown in Table 1. Not surprisingly, given the world-wide financial and economic crisis of 2007-2009, the growth of world GDP decelerated to 3.06 percent in 2005-2009. We can underscore the significance of 
more rapid growth by pointing out that GDP growth of 2.20 percent doubles world output every 32 years, while 3.71 percent growth doubles world output in less than 19 years.

To analyze the restructuring of the world economy, we first consider the shares of world product and growth for the seven regions, the G7 economies, and seven leading economies of Developing Asia presented in Table 1. The G7 economies accounted for slightly over half of world product in 2000 . However, the growth rate of these economies has lagged considerably behind world growth rates. This has led to a decline of eleven percentage points in the G7 share of world product from 52.5 percent in 1990 to 41.5 percent in 2009.

The rise of Developing Asia is almost a mirror image of the decline of the G7 economies. The 16 economies of Developing Asia generated only 13.1 percent of world output in 1990 but 17.4 percent in $1995,19.2$ percent in 2000, 22.6 in 2005, and 27.5 percent in 2009. Developing Asia generated more than half of world growth during the remarkable revival of 1990-1995, but this share declined to 24.2 percent during the period 1995-2000, which includes the Asian economic crisis. These economies accounted for 43.6 percent of world growth during 2000-2005 and an astonishing 64.9 percent during 2005-2009!

The U.S. has been the world's largest economy for more than a century. By 2005 Japan had fallen from its ranking as the world's second largest economy to third largest after China, but remained second among the G7 economies. ${ }^{9}$ Germany had dropped to fourth place by 2000, following the U.S., China, and Japan, but had fallen behind India by 2009. However, Germany has retained its position as the leading European economy. France, Italy

\footnotetext{
${ }^{9}$ The World Bank's growth rates for China may be exaggerated, as pointed out by Maddison (2009).
} 
and the U.K. were considerably smaller, but similar in size. Canada was the smallest of the G7 economies.

\section{Sources of World Economic Growth.}

In this section our first objective is to allocate the growth of world output between input growth and productivity. Surprisingly, input growth greatly predominates. Productivity growth accounted for 14.1 percent of world growth during 1990-1995, while input growth accounted for the rest, as shown in Table 2. Productivity growth contributed 17.8 percent of growth in 1995-2000, but surged to 36.4 percent during the world-wide boom in 2000-2005, before plunging back to only 7.2 percent in 2005-2009.

We next allocate the sources of input growth between capital and labor inputs. The contribution of capital input exceeds that of labor input for the world economy during the period 1990-2009 and all four sub-periods. Capital input predominates for all sub-periods for the G7 industrialized economies and Developing Asia and for all regions after 2000. The growth pattern for Eastern Europe reflects the fall of the Berlin Wall and the end of communism. Growth collapsed during the period 1990-1995, but began to recover in 19952000 before booming in 2000-2005.

We have divided the contribution of capital input to world economic growth between IT capital and Non-IT capital inputs. The contribution of IT almost doubled after 1995 from less than a quarter of the contribution of capital input during 1990-1995 to almost a third from 1995-2000. The share of IT in the contribution of capital input receded slightly to less than a third after the dot-com crash of 2000 and less than a quarter after 2005. However, the contribution of Non-IT investment was more important throughout the period 1990-2009. 
All seven regions of the world economy experienced a surge in investment in IT after 1995. The soaring level of U.S. IT investment after 1995 was paralleled by jumps in IT investment throughout the industrialized world. The contributions of IT investment to growth in Developing Asia, Latin America, Eastern Europe, North Africa and the Middle East, and Sub-Saharan Africa nearly doubled after 1995, beginning from much lower levels.

The contribution of IT investment to growth of the world economy moderated after the dot-com crash of 2000, due to a fall in the contribution of IT in the G7 and Non-G7 industrialized countries. However, the contribution of IT investment continued to rise for Developing Asia, Latin America, Eastern Europe, and Sub-Saharan Africa. The contributions of Non-IT investment to world growth remained flat after the dot-com crash, but surpassed its previous levels during 2005-2009.

Our final objective is to analyze the determinants of the growth of labor input, focusing on the role of investment in human capital. We have divided labor input growth between the growth of hours worked and labor quality, where quality is defined as the ratio of labor input to hours worked. Labor quality growth captures the impact of changes in the composition of labor input arising, for example, from increases in the education and experience of the labor force. The contribution of labor input is the sum of the two components, weighted by the share of labor in output.

We have divided the contribution of labor input between hours worked and labor quality. Hours worked reflects the mobilization of labor by increased labor force participation and higher rates of utilization of labor. Hours worked have grown more strongly that labor quality in Developing Asia throughout the period 1990-2009. Growth of hours worked has been highly cyclical in the G7 economies and exceeded labor quality growth 
during 1995-2000, but was negative for the other periods. For the world economy the growth of labor quality exceeded growth of hours worked in 1990-1995, but hours worked have grown more rapidly than labor quality since 1995 .

\section{World Output, Input, and Productivity.}

The final step in analyzing the world growth resurgence is to characterize the evolution of levels of output, input, and productivity for the world economy, the seven economic regions, the G7 economies, and the seven leading countries of Developing Asia. We estimate the levels of per capita output, per capita input, and productivity for each of the 122 economies in a given year, using the following methodology:

- Per capita output is measured in 2005 PPP\$, as in the World Bank's International Comparison Program. We create the output level by standardizing to 100 for the US output level in 2000 .

- Input combines measures of capital and labor inputs:

- The per capita level of capital input is based on the per capita capital services value measured in 2005PPP\$, standardizing to 100 for the per capita level of US capital services in 2000 .

- The per capita level of labor input is a product of per capita labor hours worked and the labor quality index, standardizing to 100 for the US level in 2000.

- The level of productivity is the ratio of output to input.

Taking the U.S. levels of output, input, and productivity in 2000 as 100.0, we estimate levels of output, input, and productivity for each of the 122 economies in the benchmark years 1990, 1995, 2000, 2005, and 2009. In Table 3 we present levels of output per capita at the beginning of the transition from socialism in 1990, at the start of the 
worldwide IT investment boom in 1995, at the beginning of the dot-com crash in 2000, the completion of the recovery in 2005, and the end of the period covered by our study in 2009 . We also present input per capita and productivity for these years.

Taking U.S. output per capita in 2000 as 100.0, world output per capita was a relatively modest 17.8 in 1990 . Using similar scales for input and productivity, world input per capita in 1990 was a considerable 41.7 and world productivity a significant 42.7 . The level of world output advanced to 18.5 in 1995 , jumped to 20.7 in 2000 , and leapt again to 23.1 in 2005 , and rose to 25.1 in 2009 , reflecting slowly rising levels of world input per capita and rapid growth in productivity. World productivity rose to 43.4 in $1995,44.0$ in 2000, 47.7 in 2005, and 48.6 in 2009. This trend was most notable for Developing Asia.

We observe that world input per capita has converged more rapidly to U.S. levels than world productivity. Although institutional barriers to accumulation of human and nonhuman capital have proven to be formidable, these obstacles have been gradually overcome. As globalization has proceeded, the transfer of technologies from industrialized economies to the developing world has required time and effort. Networks among co-operating activities must be established and obsolete methods for organizing production must be displaced by up-to-date techniques that employ information technology equipment and software.

\section{Future Uncertainties.}

Our methodology for projecting the growth of labor productivity and GDP is presented in detail in Jorgenson and Vu (2010). The driving forces are demography and technology. The contributions of hours worked and labor quality can be projected with only a modest degree of uncertainty and are common to our alternative scenarios. Projections of the variables that describe technology are far more challenging. In making assumptions for each 
of these variables, we consider three scenarios: "base-case", "pessimistic", and "optimistic" and label these the alternative assumptions.

We follow the approach of Jorgenson, Ho and Stiroh (2008) in making common and alternative assumptions for our projections. First, the common assumptions are that for each economy over the period 2010-2020:

- The capital shares will be the same as the average level observed for the historical period 1990-2009.

- The value share of reproducible capital stock in aggregate capital stock for all countries will be 0.761 , the average value observed for the US over 1990-2009.

- Growth in labor hours worked for the G7 will be the projected growth rate for 2010-2020 of the population aged $15-64^{10}$. For the remaining countries the projected growth rate will be an average of growth during the past ten years and the projected growth rate of the population.

-We extrapolate labor quality growth for all the developing countries for the past ten years to 2010-2020. Since labor quality growth captures labor composition changes, we expect that this growth will slow for the industrialized countries over the coming decade. We assume the average labor quality growth for the period 2010-2020 is a half of the rate observed over the past ten years, except for the U.S., where our projections of labor quality growth are based on population projections.

- The gap between the growth rates of the reproducible capital stock and output reflects the proximity of the economy to long-run balanced growth. This gap for the period 1990-2009 is close to zero for the $\mathrm{G} 7$ economies but far from zero for most other countries. For the

\footnotetext{
${ }^{10}$ This projection is made by International Data Base (IDB), U.S. Census Bureau, Population Division; the data for all the 122 economies is available at http://www.census.gov/ipc/www/idb/informationGateway.php.
} 
period 2010-2020, we assume this gap is equal to the difference observed for the period 1990-2009 with the following exceptions: For countries in Sub-Saharan Africa and Middle East \& North Africa, we extrapolate the gap observed for the past ten years.

Our alternative assumptions for the more uncertain variables over the period 20102020 are specified in the three scenarios - "base-case", "pessimistic", and "optimistic".

- Our assumptions about capital quality growth, reflecting changes in the composition of the capital stock, are as follows.

The base-case: For the G7 economies this is the rate observed for 1990-2009. For the economies in Non-G7, Developing Asia, and Latin America, this is the average off the period 1990-2009 and 1999-2009. For Eastern Europe, Sub-Saharan Africa, and Middle East \& North Africa we expect that capital quality growth patterns will be similar to those observed in 1999-2009.

Pessimistic and optimistic cases: For the U.S. we assume the "pessimistic case" for capital quality growth is the average growth observed for 1990-1995 and 2005-2009. For the "optimistic case" we assume this growth to be the same as for 1995-2005. For the remaining economies, the "pessimistic case" and the "optimistic case" for each country is the deviation from the "base case" by one standard deviation of the base case assumed above for the economies in its economic group/region.

- Our assumptions about TFP growth over 2010-2020 is as follows: The "base-case": We assume TFP growth is will be the average observed the period 1990-2009 for all countries with the following exceptions. For the East European Economies, the high TFP growth observed for recent periods reflect their recovery from the collapse in the 1990s. For this group, we assume TFP growth is a weighted average of 2005-2009, 
2000-2009, and 1990-2009 with weights one, two, and two, respectively. For SubSaharan Africa and Middle East \& North Africa, we assume that TFP growth is the average of the past ten years. The "pessimistic" and "optimistic" scenarios: For the U.S., TFP growth for the "pessimistic" is assumed to be the sub-periods 1990-1995 and 2005-2009 average. We assume the sub-period 1995-2005 average for the "optimistic" scenario. For the other 121 economies, the "pessimistic case" and the "optimistic case" for each country is the deviation from the "base case" by one standard deviation of the base case assumed above for the economies in its economic group/region.

\section{Potential Growth of the World Economy, 2010-2020}

Based on the assumptions outlined in the previous section, we project the potential growth rates of labor productivity and GDP over the period 2010-2020 for 122 economies. Table 4 summarizes the results for the world economy, each of the seven groups, the seven major industrialized economies, and seven leading economies of Developing Asia. We consider three scenarios - "base-case", "pessimistic", and "optimistic".

Productivity growth in the United States will decline somewhat from 1.94 percent in 1990-2009 to 1.49 percent in 2010-2020. This is mainly due to slower growth in labor quality, the upgrading of the labor force due to education and experience. The baby boomers will begin to retire, reducing the level of experience. The educational attainment of age cohorts leaving the educational system has been steady for more than three decades and will be difficult to improve. These forces will reduce the growth of labor input and the rate of capital deepening. 
Second, U.S. GDP growth will decline a bit more than productivity growth, due to a modest decline in labor force growth. In short, the U.S. growth rate of the past two decades will be nearly impossible to sustain. This could only occur under very optimistic assumptions about the development of technology and the additional capital deepening that this would induce. We also present a pessimistic scenario, based on the continuation of low growth rates of total factor productivity like those that prevailed after 2005 and before 1995 .

Growth of the world economy will decline by less than a quarter of a percentage point, relative to the robust growth of the past two decades. This is due mainly to the gradual slowing of labor force growth around the world and the reduced capital deepening that will result. Growth in the G7, already relatively low during the past two decades, will decline further. The feverish growth of Developing Asia will also slow by almost a full percentage point. Nonetheless, the growth rate differential between the two regions will be more than four percentage points, so that the wide remaining gap in levels of GDP per capita will close at rapid pace.

Although the growth of Developing Asia will slow during 2010-2020, relative to the past decade, the share of Developing Asia in World GDP will continue to rise from 28.6 in 2010 to 36.8 percent in 2020. Meanwhile, the share of the G7 will decline from 40.6 percent in 2010 to 33.3 percent in 2020. With this projected pattern of economic growth Developing Asia will overtake the G7 by 2018. ${ }^{11}$ In our projections China will overtake the U.S. by 2018 and India will surpass Japan in 2011.

U.S. growth will continue to lead the G7, even with the slowdown we have analyzed. All the G7 countries will slow further and growth could disappear entirely in Italy under

\footnotetext{
${ }^{11}$ In this projection, we assume that the PPP exchange rates observed in 2009 will remain unchanged over 20102020 .
} 
pessimistic assumptions. The mediocre growth rate of Japan for the past two decades will be further reduced, due to strongly adverse demographic trends. Growth in the United Kingdom will surpass the pace of the past two decades. Despite relatively favorable demographics and substantial investment, U.K. growth will lag behind growth of the world economy.

It is difficult to paint an optimistic picture of the outlook for Europe and Canada. The major European countries failed to make the transition to a knowledge economy called for by the Lisbon Agenda ten years ago. The European Union has made little progress in formulating a policy response in its more recent report, Europe 2020. This is understandable in view of more pressing policy issues arising from the ongoing fiscal and financial crisis. Canada has come through the crisis very well, especially given its proximity to the U.S. However, Canadian productivity growth will remain below U.S. levels.

Turning, finally, to the emerging and transition economies, the outlook for China and India continues to be very sanguine, but quite different. Growth rates in China will fall, relative to the blistering pace of the past two decades, while remaining in the neighborhood of 7.5 percent per year. India's growth rate will rise to 6.5 percent, which is not sufficient to avoid a considerable fiscal consolidation. Russia's growth will be sufficient to double the size of the Russian economy within two decades and Russia will overtake Germany in 2019. Brazil will grow at the same rate as the world economy and will overtake the U.K. in 2012.

\section{Conclusions.}

The emergence of Asia from the underdevelopment that persisted until the middle of the last century is the great economic success story of our times. This has created a new model for economic growth built on globalization and the patient accumulation of human and nonhuman capital over decades. The new growth paradigm places a premium on skillful 
management by public and private authorities. The performance of the leading countries in developing this paradigm - first Japan, then the Asian Tigers, and now China and India - has changed the course of economic development in Asia and around the world. While the Rise of Asia will be firmly established by 2020, pessimistic trends in demography will further undercut growth in Japan and will eventually affect growth prospects in Korea and China. Demographic developments in Europe will also exert a powerful drag on growth. No reform initiatives are within sight that could change the pessimistic outlook for technology in Europe and Canada, but successful educational investments in Asia and Europe and around the world, except for the United States, will help to sustain economic growth.

The role of the U.S. in the world economy has permanently changed and not for the better. Unfortunately, this will strengthen populist forces on the left and right, diverting attention from the policy issues that have emerged from the financial and economic crisis. Ideological battles threaten to overwhelm the unfinished agenda of formulating and implementing sustainable fiscal and monetary policies. To quote Winston Churchill: "You can always count on Americans to do the right thing - after they've tried everything else."

For professional economists the task that remains is to construct an empirical theory of economic growth that can serve as a guide to policy. The United States and other industrialized countries will remain far in advance of Developing Asia in terms of per capita GDP. But the experience of Japan and the four Asian Tigers tells us the advanced economies can emerge outside Europe and North America. It is only a matter of time until these developments spread to China, India, and the major countries of Developing Asia. We have shown in this paper that this time will be measured in decades rather than years. 


\section{References}

Bureau of Economic Analysis (2011), Fixed Assets Accounts Tables, see: http://www.bea.gov/national/FA2004/index.asp

Bureau of Labor Statistics (1983), Trends in Multifactor Productivity, 1948-1981, Washington, DC, U.S. Government Printing Office.

(1993), "Labor Composition and U.S. Productivity Growth, 1948-1990,"

Bureau of Labor Statistics Bulletin 2426, Washington, DC: U.S. Department of Labor.

Conference Board (2011), Total Economy Data Base. See: http://www.conferenceboard.org/data/economydatabase/

International Monetary Fund (2011), World Economic Outlook, April. See: http://www.imf.org/external/pubs/ft/weo/2011/01/index.htm

Jorgenson, Dale W. (1963), “Capital Theory and Investment Behavior,” American Economic Review, Vol. 53, No. 2, May, pp. 247-259.

(2001), "Information Technology and the U.S. Economy," American Economic Review, Vol. 91, No. 1, March, pp. 1-32.

Jorgenson, Dale W., Mun S. Ho, and Kevin J. Stiroh (2008), “A Retrospective Look at the U.S. Productivity Resurgence," Journal of Economic Perspectives, Vol. 22, No. 1, Winter, pp. 3-24.

Jorgenson, Dale W., and J. Steven Landefeld (2006), "Blueprint for Expanded and Integrated U.S. Accounts: Review, Assessment, and Next Steps,” in Dale W. Jorgenson, J. Steven Landefeld, and William D. Nordhaus, eds., A New Architecture for the U.S. National Accounts, Chicago: University of Chicago Press, pp. 13-112. 
Jorgenson, Dale W., and Khuong Vu (2010), "Potential Growth of the World Economy," Journal of Policy Modeling, Vol. 32, Issue 5, September-October, 615-631.

Maddison, Angus (2006), The World Economy. Paris: Organisation for Economic Cooperation and Development.

Schreyer, Paul. (2001). Productivity Manual: A Guide to the Measurement of Industry-Level and Aggregate Productivity Growth. Paris: Organisation for Economic Cooperation and Development, May.

_. (2009). OECD Manual: Measuring Capital. Paris: Organisation for Economic Cooperation and Development, January. .

United Nations, Commission of the European Communities, International Monetary Fund, Organisation for Economic Co-operation and Development, and World Bank (1993), System of National Accounts 1993. Series F, no. 2, rev. 4, New York: United Nations. (2009), 2008 System of National Accounts.

See: http://unstats.un.org/unsd/nationalaccount/sna2008.asp

United Nations Statistical Commission (2007), Report of the Intersecretariat Working Group on National Accounts, Series E. CN.3/2007/7, New York: United Nations, Economic and Social Council, February-March.

World Bank (2008), Global Purchasing Power Parities and Real Expendditures: 2005 International Comparison Program, Washington, D.C.: The World Bank.

World Information Technology and Services Alliance (2010), Digital Planet Report, Washington, DC: World Information Technology and Services Alliance, see: http://www.witsa.org 
Table 1: The World Economy: Shares in Size and Growth by Group, Region, and Economy

\begin{tabular}{|c|c|c|c|c|c|c|c|c|c|c|c|c|c|}
\hline \multirow[b]{2}{*}{ Group } & \multicolumn{2}{|c|}{ 1990-1995 } & \multicolumn{2}{|c|}{ 1995-2000 } & \multicolumn{2}{|c|}{ 2000-2005 } & \multicolumn{2}{|c|}{ 2005-2009 } & \multicolumn{5}{|c|}{ GDP Share in World } \\
\hline & \begin{tabular}{|c|} 
GDP \\
Growth
\end{tabular} & $\begin{array}{l}\text { Growth } \\
\text { Share }\end{array}$ & \begin{tabular}{|c|} 
GDP \\
Growth \\
\end{tabular} & \begin{tabular}{|l} 
Growth \\
Share
\end{tabular} & $\begin{array}{c}\text { GDP } \\
\text { Growth }\end{array}$ & $\begin{array}{l}\text { Growth } \\
\text { Share }\end{array}$ & \begin{tabular}{|c|} 
GDP \\
Growth \\
\end{tabular} & $\begin{array}{l}\text { Growth } \\
\text { Share }\end{array}$ & 1990 & 1995 & 2000 & 2005 & 2009 \\
\hline onomies) & 2.20 & 100.00 & 3.37 & 100.00 & 3.71 & 100.00 & 3.06 & 100.00 & 100.00 & 100.00 & 100.00 & 100.00 & 100.00 \\
\hline & 1.91 & 45.37 & 3.08 & 46.40 & 2.01 & 25.98 & 0.38 & 5.39 & 52.50 & 51.79 & 50.11 & 46.22 & 41.48 \\
\hline Developing Asia & 7.38 & 52.36 & 4.40 & 24.18 & 7.68 & 43.61 & 7.87 & 64.88 & 13.08 & 17.35 & 19.16 & 22.59 & 27.52 \\
\hline Non-G7 & 2.06 & 8.99 & 3.76 & 10.67 & 2.52 & 6.51 & 1.27 & 3.75 & 9.71 & 9.53 & 9.76 & 9.26 & 8.68 \\
\hline Latin A & 3.38 & 13.64 & 2.91 & 7.58 & 2.71 & 6.13 & 3.19 & 9.01 & 8.38 & 8.89 & 8.56 & 8.57 & 8.63 \\
\hline Eastern Europe & -7.43 & -27.23 & 2.27 & 4.21 & 5.53 & 9.99 & 3.48 & 8.54 & 10.72 & 6.72 & 6.25 & 6.93 & 7.03 \\
\hline Sub-Sahara Afric & 1.77 & 1.67 & 3.44 & 2.10 & 4.65 & 2.62 & 4.73 & 3.41 & 2.11 & 2.06 & 2.03 & 2.15 & 2.30 \\
\hline N. Africa and Middle-East & 3.10 & 5.19 & 4.11 & 4.86 & 4.64 & 5.16 & 3.52 & 5.02 & 3.50 & 3.66 & 4.13 & 4.28 & 4.37 \\
\hline
\end{tabular}

\begin{tabular}{|c|c|c|c|c|c|c|c|c|c|c|c|c|c|c|c|c|c|c|c|c|c|c|}
\hline \multirow{3}{*}{ Economy } & \multicolumn{3}{|c|}{ 1990-1995 } & \multicolumn{3}{|c|}{$1995-2000$} & \multicolumn{3}{|c|}{$2000-2005$} & \multicolumn{3}{|c|}{ 2005-2009 } & \multirow{2}{*}{\multicolumn{5}{|c|}{ GDP Share in World }} & \multirow{2}{*}{\multicolumn{5}{|c|}{ GDP Share in Group }} \\
\hline & \multirow{2}{*}{$\begin{array}{c}\text { GDP } \\
\text { Growth }\end{array}$} & \multicolumn{2}{|c|}{ Growth Share } & \multirow{2}{*}{$\begin{array}{l}\text { GDP } \\
\text { Growth }\end{array}$} & \multicolumn{2}{|c|}{ Growth Share } & \multirow{2}{*}{$\begin{array}{c}\text { GDP } \\
\text { Growth }\end{array}$} & \multicolumn{2}{|c|}{ Growth Share } & \multirow{2}{*}{$\begin{array}{c}\text { GDP } \\
\text { Growth }\end{array}$} & \multicolumn{2}{|c|}{ Growth Share } & & & & & & & & & & \\
\hline & & Group & World & & Group & World & & Group & World & & Group & World & 1990 & 1995 & \multirow{2}{*}{$\frac{2000}{213}$} & \multirow{2}{*}{$\begin{array}{l}2005 \\
2.06\end{array}$} & \multirow{2}{*}{$\begin{array}{l}2009 \\
1.87\end{array}$} & \multirow{2}{*}{1990} & \multirow{2}{*}{$\begin{array}{l}1995 \\
4.11\end{array}$} & \multirow{2}{*}{$\begin{array}{l}2000 \\
4.26\end{array}$} & \multirow{2}{*}{$\begin{array}{l}2005 \\
4.46\end{array}$} & \multirow{2}{*}{\begin{tabular}{|l|}
2009 \\
4.50
\end{tabular}} \\
\hline Canada & 1.71 & 3.63 & 1.65 & 4.05 & 5.48 & 2.54 & 2.51 & 5.42 & 1.41 & 0.75 & 8.65 & 0.47 & 2.19 & 2.13 & & & & & & & & \\
\hline Franc & 1.15 & 4.55 & 2.06 & 2.77 & 6.62 & 3.07 & 1.65 & 6.17 & 1.60 & 0.52 & 10.08 & 0.54 & 4.06 & 3.84 & 3.75 & 3.40 & 3.06 & 7.74 & 7.42 & 7.47 & 7.35 & 7.37 \\
\hline Germany & 2.17 & 13.14 & 5.96 & 1.99 & 6.94 & 3.22 & 0.59 & 3.04 & 0.79 & 0.52 & 13.89 & 0.75 & 5.90 & 5.88 & 5.20 & 4.71 & 4.23 & 11.24 & 11.35 & 10.39 & 10.18 & 10.19 \\
\hline Italy & 1.26 & 4.98 & 2.26 & 1.88 & 4.40 & 2.04 & 0.88 & 3.00 & 0.78 & -0.75 & -12.75 & -0.69 & 4.03 & 3.84 & 3.56 & 3.00 & 2.56 & 7.68 & 7.41 & 7.10 & 6.48 & 6.18 \\
\hline Japan & 1.40 & 13.07 & 5.93 & 0.95 & 5.11 & 2.37 & 1.29 & 9.94 & 2.58 & -0.54 & -21.15 & -1.14 & 9.38 & 9.04 & 7.93 & 7.04 & 6.06 & 17.87 & 17.46 & 15.83 & 15.23 & 14.62 \\
\hline United Kingdom & 1.63 & 5.89 & 2.67 & 3.38 & 7.91 & 3.67 & 2.47 & 9.38 & 2.44 & 0.05 & 1.09 & 0.06 & 3.71 & 3.61 & 3.68 & 3.53 & 3.18 & 7.07 & 6.97 & 7.34 & 7.63 & 7.67 \\
\hline United States & 2.34 & 54.75 & 24.84 & 4.18 & 63.53 & 29.48 & 2.65 & 63.05 & 16.38 & 0.78 & 100.20 & 5.40 & 23.22 & 23.45 & 23.86 & 22.50 & 20.52 & 44.22 & 45.27 & 47.61 & 48.67 & 49.48 \\
\hline All group & 1.91 & 100.00 & 45.37 & 3.08 & 100.00 & 46.40 & 2.01 & 100.00 & 25.98 & 0.38 & 100.00 & 5.39 & 52.50 & 51.79 & 50.11 & 46.22 & 41.48 & 100.00 & 100.00 & 100.00 & 100.00 & 100.00 \\
\hline
\end{tabular}

\begin{tabular}{|c|c|c|c|c|c|c|c|c|c|c|c|c|c|c|c|c|c|c|c|c|c|c|}
\hline \multirow{3}{*}{ Economy } & \multicolumn{3}{|c|}{ 1990-1995 } & \multicolumn{3}{|c|}{$1995-2000$} & \multicolumn{3}{|c|}{$2000-2005$} & \multicolumn{3}{|c|}{ 2005-2009 } & \multirow{2}{*}{\multicolumn{5}{|c|}{ GDP Share in World }} & \multirow{2}{*}{\multicolumn{5}{|c|}{ GDP Share in Group }} \\
\hline & GDP & Growt & Share & GDP & Growth S & hare & GDP & Growth & Share & GDP & Growth & Share & & & & & & & & & & \\
\hline & Growth & Group & World & Growth & Group & World & Growth & Group & World & Growth & Group & World & 1990 & 1995 & 2000 & 2005 & 2009 & 1990 & 1995 & 2000 & 2005 & 2009 \\
\hline China & 9.70 & 48.58 & 21.58 & 4.49 & 42.67 & 8.97 & 11.09 & 65.70 & 25.87 & 10.80 & 68.06 & 41.02 & 3.63 & 5.79 & 7.27 & 9.66 & 13.21 & 34.33 & 40.42 & 44.94 & 49.88 & 54.79 \\
\hline Hong Kong & 5.08 & 2.29 & 1.02 & 2.63 & 1.62 & 0.34 & 4.05 & 1.18 & 0.46 & 3.08 & 0.74 & 0.45 & 0.39 & 0.45 & 0.43 & 0.44 & 0.44 & 3.72 & 3.17 & 2.65 & 2.28 & 1.82 \\
\hline India & 5.08 & 16.62 & 7.38 & 5.78 & 29.89 & 6.29 & 6.76 & 19.03 & 7.49 & 7.94 & 21.57 & 13.00 & 2.99 & 3.42 & 3.77 & 4.44 & 5.54 & 28.22 & 23.88 & 23.32 & 22.95 & 22.95 \\
\hline Indonesia & 7.54 & 9.91 & 4.40 & 0.73 & 1.35 & 0.28 & 4.62 & 3.96 & 1.56 & 5.46 & 3.91 & 2.36 & 1.08 & 1.41 & 1.21 & 1.28 & 1.40 & 10.18 & 9.82 & 7.48 & 6.62 & 5.82 \\
\hline Singapore & 8.47 & 2.22 & 0.98 & 6.13 & 2.68 & 0.56 & 5.34 & 1.18 & 0.46 & 4.24 & 0.83 & 0.50 & 0.21 & 0.29 & 0.33 & 0.34 & 0.37 & 2.00 & 2.02 & 2.02 & 1.75 & 1.52 \\
\hline South Korea & 7.59 & 13.05 & 5.80 & 5.06 & 13.35 & 2.81 & 4.39 & 6.10 & 2.40 & 3.12 & 3.30 & 1.99 & 1.42 & 1.85 & 1.97 & 1.99 & 1.99 & 13.40 & 12.88 & 12.16 & 10.29 & 8.25 \\
\hline Taiwan & 6.98 & 7.33 & 3.26 & 5.11 & 8.43 & 1.77 & 3.53 & 2.86 & 1.13 & 2.48 & 1.59 & 0.96 & 0.86 & 1.12 & 1.20 & 1.20 & 1.17 & 8.16 & 7.81 & 7.43 & 6.22 & 4.85 \\
\hline All group & 7.64 & 100.00 & 44.43 & 4.57 & 100.00 & 21.03 & 8.12 & 100.00 & 39.37 & 8.42 & 100.00 & 60.27 & 10.59 & 14.33 & 16.18 & 19.36 & 24.12 & 100.00 & 100.00 & 100.00 & 100.00 & 100.00 \\
\hline
\end{tabular}


Table 2. Sources of Output Growth by Period

\begin{tabular}{|c|c|c|c|c|c|c|c|c|c|c|c|c|c|c|c|c|c|c|c|c|c|c|c|c|c|c|c|c|c|c|c|c|}
\hline \multirow{3}{*}{ Economy } & \multirow{2}{*}{\multicolumn{8}{|c|}{$\begin{array}{c}\text { Period 1990-1995 } \\
\text { Sources of Growth }(\% \mathrm{ppa})\end{array}$}} & \multirow{2}{*}{\multicolumn{8}{|c|}{$\begin{array}{l}\text { Period 1995-2000 } \\
\text { Sources of Growth } \% \text { ppa) }\end{array}$}} & \multirow{2}{*}{\multicolumn{8}{|c|}{$\begin{array}{l}\text { Period 2000-2005 } \\
\text { Sources of Growth (\% ppa) }\end{array}$}} & \multicolumn{8}{|c|}{$\begin{array}{l}\text { Period 2005-2009 } \\
\end{array}$} \\
\hline & & & & & & & & & & & & & & & & & & & & & & & & & \multirow{2}{*}{ GDP } & \multicolumn{6}{|c|}{$\begin{array}{l}\text { Sources of Growth (\% ppa) } \\
\text {. }\end{array}$} & \\
\hline & Growth & \multicolumn{3}{|c|}{ 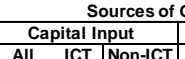 } & \multicolumn{3}{|c|}{ Labor Input } & TFP & GDP & \multicolumn{3}{|c|}{$\begin{array}{l}\text { Capital Input } \\
\text { II I I IT / Non-1 }\end{array}$} & \multicolumn{3}{|c|}{\begin{tabular}{|l|l|l|}
\multicolumn{2}{|c|}{ Labor Input } & \\
All & Quality & Hours \\
\end{tabular}} & TFP & Growth & \multicolumn{6}{|c|}{\begin{tabular}{c|c}
\multicolumn{2}{c}{ Sources of Growth (\% ppa) } \\
Capital Input & Labor Input \\
All
\end{tabular}} & TFP & & & $\begin{array}{l}\text { pital Inp } \\
\mid \\
\end{array}$ & ut & & Qor Input & Hours & \\
\hline $122 \mathrm{EcC}$ & 2.20 & 1.43 & 0.30 & 1.13 & 0.45 & 0.27 & 0.18 & 0.31 & 3.37 & 1.81 & 0.58 & 1.23 & 0.93 & 0.25 & 0.68 & 0.63 & 3.71 & 1.75 & 0.52 & 1.23 & 0.62 & 0.27 & 0.36 & 1.35 & 3.06 & 2.42 & 0.59 & 1.82 & 0.43 & 0.21 & 0.21 & 0.22 \\
\hline & 1.91 & 1.08 & 0.37 & 7 & 0.30 & 0.32 & -0.03 & & 3.08 & 1.48 & 0.73 & 0.75 & 0.86 & 0.28 & 0.58 & & 01 & 1.07 & 0.45 & 62 & 0.25 & 0.28 & & 077 & & 07 & 39 & at & م00 & ר) & -0.29 & 52 \\
\hline Devel & 7.38 & 3.66 & 0.28 & 3.38 & 1.06 & 0.22 & 0.84 & & 4.40 & 3.69 & 0.49 & 3.20 & 0.91 & 0.26 & 0.65 & -0.20 & 8 & 3.73 & 0.65 & 10 & 0.94 & 0.24 & 0.70 & 3.00 & 7.87 & 8 & 31 & 7 & 0.77 & 0.17 & 59 & 2.23 \\
\hline & 2.06 & 1.05 & 0.37 & 0.68 & 0.38 & 0.38 & -0.01 & & 3.76 & 1.54 & 0.57 & 0.9 & 1.58 & 30 & 1.28 & 34 & 52 & 1.43 & 0.48 & & 1.05 & 0.40 & 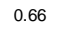 & 0.00 & & 1.63 & 0.54 & & 0.53 & 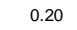 & 34 & -0.89 \\
\hline Latin A & 3.38 & 1.29 & 0.14 & 1.15 & 0. & 0.1 & 0.7 & & 2.91 & 2.01 & 0.33 & 1.6 & 1.07 & & 0.92 & & & 1.67 & 0.48 & & 1.15 & 0.16 & & -0.12 & & 20 & 1.07 & & 0.99 & & 3 & 0 \\
\hline Easten & -7.43 & -0.03 & 0.11 & -0.13 & -1.11 & 0.0 & 11 & 0 & 2. & -0.84 & 0.22 & -1. & -0.17 & 6 & -0.23 & 28 & & 0.07 & 0.44 & & 0.55 & 26 & & & & 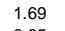 & & & & & 7 & 36 \\
\hline Sub-Sal & 1.77 & 1.09 & 0.30 & 0.79 & $1 . \varepsilon$ & 0.18 & 1.67 & & 3.44 & 1.54 & 0.48 & 1.06 & 1.80 & 0.21 & 1. & 10 & 4.65 & 2.43 & 0.66 & & 1.45 & 17 & & 10 & & 38 & & & & & 0 & \\
\hline Afric & 3.10 & 1.69 & 0.14 & 1.54 & 1.7 & 0.19 & 1.55 & -0.34 & 4.11 & 1.65 & 0.22 & 1.43 & 1.39 & 0.22 & 1.17 & & 4.64 & & 0.77 & 84 & & 0.16 & & & 3.52 & & & 2.84 & 03 & 16 & 87 & \\
\hline
\end{tabular}

\begin{tabular}{|c|c|c|c|c|c|c|c|c|c|c|c|c|c|c|c|c|c|c|c|c|c|c|c|c|c|c|c|c|c|c|c|c|}
\hline \multirow{3}{*}{ Economy } & \multicolumn{8}{|c|}{ Period 1990-1995 } & \multicolumn{8}{|c|}{ Period 1995-2000 } & \multirow{2}{*}{\multicolumn{8}{|c|}{$\begin{array}{l}\text { Period 2000-2005 } \\
\text { Sources of Growth (\% ppa) }\end{array}$}} & \multirow{2}{*}{\multicolumn{8}{|c|}{$\begin{array}{c}\text { Period 2005-2009 } \\
\text { Sources of Growth (\% pDa) }\end{array}$}} \\
\hline & \multirow{2}{*}{\begin{tabular}{c|} 
GDP \\
Growth
\end{tabular}} & \multirow{2}{*}{\multicolumn{6}{|c|}{\begin{tabular}{l|c}
\multicolumn{2}{c}{ Sources of Growth (\% ppa) } \\
ital Input & Labor Input \\
\end{tabular}}} & \multirow[b]{2}{*}{ TFP } & \multirow{2}{*}{\begin{tabular}{|c|} 
GDP \\
Growth
\end{tabular}} & \multirow{2}{*}{\multicolumn{6}{|c|}{\begin{tabular}{l|l}
\multicolumn{2}{l}{ Sources of Growth (\% ppa) } \\
pital Input & Labor Input \\
\end{tabular}}} & \multirow[b]{2}{*}{ TFP } & & \multirow{2}{*}{\multicolumn{6}{|c|}{$\begin{array}{l}\text { Sources of Growth (\% ppa) } \\
\text { Capital Input } \\
\text { Labor Input }\end{array}$}} & \multirow{3}{*}{ TFP } & \multirow{3}{*}{\begin{tabular}{|c|} 
GDP \\
Growth \\
\end{tabular}} & \multirow{2}{*}{\multicolumn{6}{|c|}{\begin{tabular}{|c|c|}
\multicolumn{2}{c}{ Sources of Growth (\% ppa) } \\
Capital Input & Labor Input
\end{tabular}}} & \\
\hline & & & & & & & & & & & & & & & & & $\begin{array}{l}\text { GDP } \\
\text { Growth } \\
\text { G }\end{array}$ & & & & & & & & & & & & & & & \\
\hline & 1.71 & 0.86 & 0.32 & 0.54 & 0.69 & 0.60 & 0.09 & 0.16 & 5 & $\frac{\text { An }}{1.49}$ & 0.53 & & 1.80 & 0.50 & 1.30 & 0.76 & 51 & $\frac{\mathrm{nl}}{1.45}$ & 0.46 & 0.99 & $\frac{\text { All }}{1.16}$ & $\frac{0.22}{0.22}$ & 0.94 & & & $\frac{\mathrm{All}}{1.61}$ & 0.54 & & $\frac{\mathrm{Al}}{0.48}$ & 0.20 & & -1.34 \\
\hline & 1 & 1.07 & 0.34 & & & 0. & & & & 1.12 & 0.44 & & & & . & & & 1.19 & 0.44 & & & & & & & & & & & & & \\
\hline & 2.17 & 0.94 & 0.34 & 0.60 & & 0.6 & -0.2 & & & 0.72 & 0.36 & & -0.08 & & 0. & & & 0.47 & 0.27 & & & & -0.47 & & & & & & & & & 37 \\
\hline & 1.26 & 0.65 & 0.19 & 0.46 & -0.43 & 0.1 & -0.5 & & & 0.99 & 0.39 & & 0.88 & & 0.6 & & & 0.99 & 0.20 & & & & & & & & & & & & & 35 \\
\hline & 1.40 & 1.75 & 0.25 & & -0.12 & & -0. & & & 1.14 & 0.40 & & -0.21 & & & & & 0.57 & 0.25 & & & & & & & & & & & & & 60 \\
\hline United K & 1.63 & 0.66 & 0.22 & & -1. & & -21 & & & 1.54 & 0.92 & & 1.2 & & 0 & & & 1.06 & 0.58 & & & & & & & & & & & & & \\
\hline & 2.34 & 1.01 & 0.48 & 0.5 & 0.5 & 0.31 & 0.6 & & & 1.90 & 1.0 & & 13 & & 1. & & & 1.32 & 0.58 & & & & & & & & & & & & & \\
\hline Grot & 1.91 & 1.08 & 0.37 & 71 & 0.5 & 0.32 & -0.03 & 0. & 3.08 & 1.48 & 0.73 & 0.75 & 0.86 & 0.28 & 0.58 & 0.74 & 2.01 & 1.07 & 0.45 & 62 & 0.25 & 0.28 & -0.0 & .70 & 0.38 & 0.93 & 0.39 & 0.54 & -0.02 & 0.27 & -0.29 & 2 \\
\hline
\end{tabular}

\begin{tabular}{|c|c|c|c|c|c|c|c|c|c|c|c|c|c|c|c|c|c|c|c|c|c|c|c|c|c|c|c|c|c|c|c|c|}
\hline \multirow{3}{*}{ Economy } & \multirow{2}{*}{\multicolumn{8}{|c|}{$\begin{array}{c}\text { Period 1990-1995 } \\
\text { Sources of Growth (\% ppa) }\end{array}$}} & \multirow{2}{*}{\multicolumn{8}{|c|}{\begin{tabular}{|l} 
Period 1995-2000 \\
Sources of Growth (\% ppa)
\end{tabular}}} & \multirow{2}{*}{\multicolumn{8}{|c|}{\begin{tabular}{|l} 
Period 2000-2005 \\
Sources of Growth (\% ppa)
\end{tabular}}} & \multirow{2}{*}{\multicolumn{8}{|c|}{$\begin{array}{c}\text { Period 2005-2009 } \\
\text { Sources of Growth (\% ppa) }\end{array}$}} \\
\hline & \multirow{2}{*}{$\begin{array}{l}\text { GDP } \\
\text { Growth }\end{array}$} & \multirow{2}{*}{\multicolumn{6}{|c|}{\begin{tabular}{c|c}
\multicolumn{2}{c}{ Sources of Growth (\% ppa) } \\
\begin{tabular}{c|c} 
Capital Input \\
Cabor Input
\end{tabular} \\
\end{tabular}}} & \multirow{2}{*}{ TFP } & & & & & & & & & & \multirow{2}{*}{\multicolumn{3}{|c|}{$\begin{array}{c}\text { Sources o } \\
\text { Capital Input } \\
\end{array}$}} & & & & & \multirow{2}{*}{ Growth } & & & & & & & \multirow[b]{2}{*}{ TF } \\
\hline & & & & & & & & & GDP & \multicolumn{3}{|c|}{$\begin{array}{l}\text { Sources o } \\
\text { Capital Input } \\
\end{array}$} & \multicolumn{3}{|c|}{\begin{tabular}{|c|} 
Labor Input \\
\end{tabular}} & TFP & Growth & & & & \multicolumn{3}{|c|}{$\begin{array}{l}\text { Labor Input } \\
\text { All |Quality } \mathrm{H}\end{array}$} & TFP & & \multicolumn{3}{|c|}{\begin{tabular}{l}
\multicolumn{2}{|c|}{ Capital Input } \\
All
\end{tabular}} & \multicolumn{3}{|c|}{ Labor Input } & \\
\hline & & 4.97 & & 4.74 & 0.65 & & & & 9 & 5.38 & & & 0.74 & 0.17 & & & & & & & 0.63 & 0.15 & & 4.58 & 10.80 & & & & & & & \\
\hline & & 2.29 & & & 0.71 & & & & 2.63 & 2.01 & 0.55 & & 1.08 & & & & & 1.04 & 0.31 & & 0.58 & & & & 8 & 0.9 & & & & & & \\
\hline & 5.08 & 2.64 & & & 1.17 & & 1.0 & & 78 & 3.06 & 0.32 & & 0.9 & & 31 & 1.74 & 6.76 & 3.31 & & & 37 & & & 08 & 64 & 4.79 & & & & & & .99 \\
\hline & 7.54 & 3.69 & 0.26 & 0.4 & 0.70 & 0.1 & 0.55 & & 0.73 & 2.54 & 0.16 & 2. & 1.33 & 0.18 & 1.15 & -3.14 & 4.62 & 1.04 & 0.29 & 0.75 & 0.61 & 6 & 0.45 & 2.97 & 16 & 2.28 & & & 44 & 17 & 36 & 1.64 \\
\hline yape & 8.47 & 5.72 & 0.60 & $5.1\}$ & 1.51 & & 0.97 & & 6.13 & 5.47 & 1.00 & 4. & 2.80 & 0.72 & 2.08 & -2.13 & 5.34 & 2.17 & 0.81 & 1.36 & I. & 10 & 0.7 & 1.98 & 24 & 3.53 & & & & 0.43 & & .83 \\
\hline uth Ko & 7.5 & 1.94 & 0.41 & 1.5 & 2.6 & & 1.8 & & 66 & 1.68 & 0.81 & 0.8 & 0.59 & 3 & -0.35 & 2.79 & 4.39 & 1.41 & & & & & & 1.92 & & 1.40 & 0.33 & & & 25 & 43 & 1.90 \\
\hline Wall & 6.98 & 2.92 & 0.44 & 24 & 1.01 & & 0.7 & & & 2.67 & 0.48 & & 0.5 & 0.30 & 0.2 & 1.88 & 38 & 1.44 & 0.38 & 1 & & 0 & & 1.72 & & 1.0 & & & & & 05 & 1.23 \\
\hline$\| l \mid$ Group & 7.64 & 3.61 & 0.27 & 3.34 & 1.09 & 0.24 & 0.85 & 2.94 & 4.57 & 3.85 & 0.51 & 3.34 & 0.87 & 0.29 & 0.58 & -0.14 & 12 & 3.98 & 0.69 & 3.29 & 0.84 & 0.25 & 59 & 3.31 & 42 & 5.17 & .83 & 4.34 & 0.66 & 0.16 & 0.50 & 8 \\
\hline
\end{tabular}


Table 3: Levels of Output and Input Per Capita and Productivity (U.S. $=100$ in 2000)

* The levels for group and the world are averages weighted by population share

\begin{tabular}{|c|c|c|c|c|c|c|c|c|c|c|c|c|c|c|c|}
\hline \multirow{2}{*}{ Group Summaries } & \multicolumn{5}{|c|}{ Output Per Capita } & \multicolumn{5}{|c|}{ Input Per Capita } & \multicolumn{5}{|c|}{ Productivity } \\
\hline & 1990 & 1995 & 2000 & 2005 & 2009 & 1990 & 1995 & 2000 & 2005 & 2009 & 1990 & 1995 & 2000 & 2005 & 2009 \\
\hline World & 17.82 & 18.49 & 20.66 & 23.11 & 25.09 & 41.72 & 42.57 & 46.98 & 48.47 & 51.59 & 42.72 & 43.43 & 3.98 & 47.67 & 48.64 \\
\hline G7 & 71.01 & 75.56 & 85.039 & 90.59 & 90.18 & 82.35 & 85.10 & 92.25 & 94.95 & 96.46 & 86.23 & 88.79 & 92.19 & 95.41 & 93.49 \\
\hline Developing Asia & 4.26 & 5.83 & 7.2017 & 9.54 & 12.67 & 16.62 & 19.94 & 25.00 & 28.73 & 35.13 & 25.63 & 29.23 & 28.80 & 33.21 & 36.06 \\
\hline Non-G7 & 57.72 & 61.21 & 71.74 & 77.43 & 79.14 & 71.62 & 73.84 & 84.15 & 90.95 & 96.15 & 80.59 & 82.90 & 85.25 & 85.13 & 82.31 \\
\hline Latin America & 18.35 & 19.88 & 21.373 & 22.97 & 25.04 & 29.99 & 30.82 & 33.52 & 36.16 & 40.96 & 61.21 & 64.49 & 63.77 & 63.52 & 61.13 \\
\hline Eas & 24.68 & 17.11 & 19.269 & 25.75 & 29.60 & 39.05 & 37.55 & 36.04 & 37.08 & 40.25 & 63.20 & 45.56 & 53.47 & 69.44 & 73.55 \\
\hline Sub-Sah & 4.39 & 4.178 & 4.3387 & 4.84 & 5.32 & 15.39 & 15.36 & 15.74 & 16.85 & 18.73 & 28.53 & 27.20 & 27.56 & 28.72 & 28.37 \\
\hline N. Africa \& M. East & 13.04 & 13.74 & 15.317 & 17.56 & 19.07 & 24.95 & 26.93 & 28.53 & 31.28 & 34.45 & 52.27 & 51.02 & 53.69 & 56.12 & 55.37 \\
\hline
\end{tabular}

G7 (7 Economies)

\begin{tabular}{|c|c|c|c|c|c|c|c|c|c|c|c|c|c|c|c|}
\hline \multirow[t]{2}{*}{ Economy } & \multicolumn{5}{|c|}{ Output Per Capita } & \multicolumn{5}{|c|}{ Input Per Capita } & \multicolumn{5}{|c|}{ Productivity } \\
\hline & 1990 & 1995 & 2000 & 2005 & 2009 & 1990 & 1995 & 2000 & 2005 & 2009 & 1990 & 1995 & 2000 & 2005 & 2009 \\
\hline Canada & 68.96 & 71.10 & 83.05 & 89.67 & 88.40 & 81.66 & 83.54 & 93.93 & 101.89 & 105.99 & 84.45 & 85.11 & 88.42 & 88.00 & 83.40 \\
\hline France & 63.79 & 66.26 & 74.74 & 78.53 & 77.96 & 73.28 & 75.64 & 82.12 & 85.83 & 88.81 & 87.04 & 87.59 & 91.00 & 91.50 & 87.78 \\
\hline Germany & 65.80 & 71.37 & 78.28 & 80.29 & 82.48 & 86.14 & 86.90 & 89.10 & 89.17 & 92.98 & 76.38 & 82.12 & 87.86 & 90.04 & 88.72 \\
\hline Italy & 60.81 & 64.63 & 70.89 & 71.92 & 67.97 & 68.29 & 68.91 & 75.50 & 79.92 & 79.73 & 89.05 & 93.80 & 93.89 & 89.99 & 85.24 \\
\hline Japan & 66.37 & 70.48 & 73.17 & 77.51 & 75.93 & 82.63 & 88.80 & 92.10 & 93.62 & 93.95 & 80.32 & 79.37 & 79.45 & 82.79 & 80.82 \\
\hline United Kingdom & 60.02 & 64.38 & 73.54 & 82.36 & 82.21 & 77.32 & 73.83 & 81.92 & 89.44 & 92.07 & 77.63 & 87.21 & 89.77 & 92.09 & 89.29 \\
\hline United States & 81.68 & 86.54 & 100.00 & 107.08 & 106.79 & 87.23 & 90.87 & 100.00 & 101.28 & 101.95 & 93.64 & 95.23 & 100.00 & 105.72 & 104.75 \\
\hline All Group & 71.01 & 75.56 & 85.04 & 90.59 & 90.18 & 82.35 & 85.10 & 92.25 & 94.95 & 96.46 & 86.23 & 88.79 & 92.19 & 95.41 & 93.49 \\
\hline
\end{tabular}

\begin{tabular}{|c|c|c|c|c|c|c|c|c|c|c|c|c|c|c|c|}
\hline \multirow[t]{2}{*}{ Economy } & \multicolumn{5}{|c|}{ Output Per Capita } & \multicolumn{5}{|c|}{ Input Per Capita } & \multicolumn{5}{|c|}{ Productivity } \\
\hline & 1990 & 1995 & 2000 & 2005 & 2009 & 1990 & 1995 & 2000 & 2005 & 2009 & 1990 & 1995 & 2000 & 2005 & 2009 \\
\hline China & 2.81 & 4.72 & 6.81 & 10.42 & 15.86 & 11.94 & 16.34 & 25.57 & 31.12 & 41.30 & 23.55 & 28.90 & 26.64 & 33.50 & 38.39 \\
\hline Hong Kong & 60.60 & 72.41 & 76.17 & 91.24 & 100.39 & 76.61 & 82.52 & 88.83 & 94.22 & 97.92 & 79.10 & 87.76 & 85.75 & 96.84 & 102.51 \\
\hline India & 3.09 & 3.61 & 4.39 & 5.71 & 7.65 & 14.06 & 15.40 & 17.20 & 20.15 & 24.94 & 21.96 & 23.42 & 25.54 & 28.34 & 30.69 \\
\hline Indonesia & 5.31 & 7.17 & 6.94 & 8.18 & 9.75 & 17.52 & 20.21 & 22.88 & 23.23 & 25.94 & 30.32 & 35.49 & 30.33 & 35.19 & 37.58 \\
\hline Singapore & 61.00 & 80.57 & 95.80 & 111.89 & 117.58 & 64.37 & 79.89 & 105.70 & 111.80 & 131.55 & 94.77 & 100.84 & 90.63 & 100.09 & 89.38 \\
\hline South Korea & 29.11 & 40.31 & 47.90 & 58.26 & 65.19 & 47.67 & 56.67 & 58.59 & 64.74 & 67.16 & 61.07 & 71.12 & 81.76 & 89.99 & 97.08 \\
\hline Taiwan & 38.32 & 51.80 & 64.12 & 74.37 & 81.37 & 66.43 & 77.10 & 86.88 & 92.46 & 96.30 & 57.69 & 67.19 & 73.81 & 80.43 & 84.49 \\
\hline All Group & 4.17 & 5.85 & 7.43 & 10.09 & 13.76 & 16.84 & 20.40 & 26.38 & 30.37 & 37.39 & 24.76 & 28.69 & 28.18 & 33.21 & 36.80 \\
\hline
\end{tabular}


Table 4: The World Economy: Growth Projections, 2010-2020

Note: The weight for aggregating growth by region and world is based on PPP\$ GDP in 2009

\begin{tabular}{|c|c|c|c|c|c|c|c|c|c|c|c|c|}
\hline \multirow{3}{*}{ Group Summaries } & \multicolumn{5}{|c|}{ Productivity Growth } & \multicolumn{5}{|c|}{ GDP Growth } & \multirow{2}{*}{\multicolumn{2}{|c|}{ GDP Share in World* }} \\
\hline & \multicolumn{2}{|c|}{ Actual } & \multicolumn{3}{|c|}{ Projections, 2010-2020 } & \multicolumn{2}{|r|}{ Actual } & \multicolumn{3}{|c|}{ Projections, 2010-2020 } & & \\
\hline & 1999-2009 & 1990-2009 & Pessimistic & Base-case & Optimistic & 1999-2009 & 1990-2009 & Pessimistic & \begin{tabular}{|l|} 
Base-case \\
\end{tabular} & Optimistic & 2010 & 2020 \\
\hline World (122 Economies) & 3.19 & 2.73 & 1.85 & 2.75 & 3.65 & 3.94 & 3.59 & 2.32 & 3.37 & 4.65 & 100.00 & 100.00 \\
\hline G7 Economies & 1.71 & 1.77 & 0.97 & 1.46 & 1.94 & 1.56 & 1.97 & 1.11 & 1.60 & 2.46 & 40.62 & 33.30 \\
\hline Developing Asia & 6.63 & 5.70 & 4.00 & 5.17 & 6.33 & 7.99 & 7.10 & 5.02 & 6.18 & 7.55 & 28.62 & 36.84 \\
\hline Non-G7 & 1.16 & 1.49 & 0.98 & 1.52 & 2.06 & 2.21 & 2.53 & 1.48 & 2.02 & 3.06 & 8.39 & 7.17 \\
\hline Latin America & 1.01 & 1.15 & 0.62 & 1.61 & 2.60 & 3.06 & 3.09 & 1.51 & 3.21 & 4.90 & 8.75 & 8.42 \\
\hline Eastern Europe & 4.43 & 1.57 & 1.36 & 3.91 & 6.45 & 4.95 & 1.09 & 0.38 & 3.76 & 7.33 & 6.95 & 7.07 \\
\hline Sub-Sahara Africa & 2.07 & 0.79 & 1.42 & 2.47 & 3.52 & 4.72 & 3.72 & 3.21 & 4.59 & 5.85 & 2.32 & 2.59 \\
\hline N. Africa and Middle-East & 2.54 & 1.62 & 1.83 & 2.78 & 3.72 & 4.25 & 3.90 & 2.76 & 4.24 & 4.86 & 4.35 & 4.61 \\
\hline
\end{tabular}

Note: * GDP for 2010 is estimated; GDP for 2020 is from the base-case

\begin{tabular}{|c|c|c|c|c|c|c|c|c|c|c|c|c|c|c|}
\hline \multirow{3}{*}{ Economy } & \multicolumn{5}{|c|}{ Productivity Growth } & \multicolumn{5}{|c|}{ GDP Growth } & \multirow{2}{*}{\multicolumn{2}{|c|}{ GDP Share in World ${ }^{*}$}} & \multirow{2}{*}{\multicolumn{2}{|c|}{ GDP Share in Group* }} \\
\hline & \multicolumn{2}{|c|}{ Actual } & \multicolumn{3}{|c|}{ Projections, 2010-2020 } & \multicolumn{2}{|r|}{ Actual } & \multicolumn{3}{|c|}{ Projections, 2010-2020 } & & & & \\
\hline & \begin{tabular}{|l|}
$1999-2009$ \\
\end{tabular} & 1990-2009 & Pessimistic & \begin{tabular}{|l|} 
Base-case \\
\end{tabular} & Optimistic & 1999-2009 & $1990-2009$ & Pessimistic & Base-case & Optimistic & 2010 & 2020 & 2010 & 2020 \\
\hline Canada & 0.91 & 1.34 & 1.01 & 1.47 & 1.93 & 2.06 & 2.33 & 1.28 & 1.74 & 2.57 & 1.84 & 1.52 & 4.52 & 4.58 \\
\hline France & 1.12 & 1.25 & 1.10 & 1.44 & 1.78 & 1.42 & 1.58 & 0.90 & 1.24 & 1.81 & 2.96 & 2.34 & 7.29 & 7.03 \\
\hline Germany & 1.06 & 1.69 & 0.98 & 1.37 & 1.77 & 0.82 & 1.36 & 0.63 & 1.03 & 1.62 & 4.18 & 3.23 & 10.28 & 9.70 \\
\hline Italy & 0.07 & 0.64 & -0.05 & 0.61 & 1.27 & 0.50 & 0.90 & -0.43 & 0.22 & 1.26 & 2.47 & 1.77 & 6.09 & 5.30 \\
\hline Japan & 1.65 & 1.78 & 0.96 & 1.40 & 1.84 & 0.71 & 0.84 & 0.00 & 0.43 & 1.00 & 5.95 & 4.34 & 14.64 & 13.02 \\
\hline United Kingdom & 1.45 & 2.43 & 1.56 & 2.15 & 2.75 & 1.64 & 1.98 & 1.58 & 2.17 & 3.36 & 3.08 & 2.66 & 7.58 & 8.00 \\
\hline United States & 2.27 & 1.94 & 0.99 & 1.49 & 1.99 & 2.05 & 2.58 & 1.67 & 2.18 & 3.17 & 20.14 & 17.44 & 49.59 & 52.38 \\
\hline All Group & 1.71 & 1.77 & 0.97 & 1.46 & 1.94 & 1.56 & 1.97 & 1.11 & 1.60 & 2.46 & 40.62 & ' 33.30 & 100.00 & 100.00 \\
\hline
\end{tabular}

\begin{tabular}{llllll} 
All Group & 1.71 & 1.77 & 0.97 & 1.46 \\
\hline Note: * GDP for 2010 is estimated; GDP for 2020 is from the base-case
\end{tabular}

\begin{tabular}{|c|c|c|c|c|c|c|c|c|c|c|c|c|c|c|}
\hline \multirow{3}{*}{ Economy } & \multicolumn{5}{|c|}{ Productivity Growth } & \multicolumn{5}{|c|}{ GDP Growth } & \multirow{2}{*}{\multicolumn{2}{|c|}{ GDP Share in World ${ }^{*}$}} & \multirow{2}{*}{\multicolumn{2}{|c|}{ GDP Share in Group* }} \\
\hline & \multicolumn{2}{|c|}{ Actual } & \multicolumn{3}{|c|}{ Projections, $2010-2020$} & \multicolumn{2}{|r|}{ Actual } & \multicolumn{3}{|c|}{ Projections, 2010-2020 } & & & & \\
\hline & \begin{tabular}{|l|}
$1999-2009$ \\
\end{tabular} & 1990-2009 & Pessimistic & Base-case & Optimistic & 1999-2009 & 1990-2009 & Pessimistic & Base-case & Optimistic & 2010 & 2020 & 2010 & 2020 \\
\hline China & 9.83 & 7.87 & 5.28 & 7.00 & 8.72 & 10.73 & 8.93 & 5.80 & 7.52 & 9.34 & 13.92 & 20.08 & 55.35 & 60.52 \\
\hline Hong Kong & 2.91 & 2.55 & 0.55 & 2.14 & 3.73 & 4.03 & 3.74 & 0.90 & 2.49 & 4.34 & 0.45 & 0.40 & 1.79 & 1.21 \\
\hline India & 4.73 & 4.26 & 4.23 & 4.50 & 4.77 & 6.99 & 6.31 & 6.23 & 6.49 & 6.95 & 5.71 & 7.47 & 22.68 & 22.52 \\
\hline Indonesia & 3.32 & 2.76 & 0.20 & 1.91 & 3.61 & 4.97 & 4.54 & 1.68 & 3.38 & 5.33 & 1.42 & 1.38 & 5.65 & 4.17 \\
\hline Singapore & 2.21 & 2.50 & 0.48 & 2.02 & 3.56 & 5.32 & 6.14 & 2.10 & 3.64 & 5.73 & 0.40 & 0.40 & 1.60 & 1.21 \\
\hline South Korea & 3.91 & 4.68 & 3.88 & 4.19 & 4.50 & 4.29 & 5.14 & 4.06 & 4.37 & 5.07 & 2.01 & 2.16 & 8.01 & 6.50 \\
\hline Taiwan & 3.15 & 4.15 & 3.53 & 3.91 & 4.29 & 3.32 & 4.63 & 3.64 & 4.02 & 4.68 & 1.24 & 1.28 & 4.92 & 3.86 \\
\hline All group & 7.23 & 6.12 & 4.39 & 5.58 & 6.78 & 8.44 & 7.41 & 5.27 & 6.47 & 7.83 & 25.16 & 33.18 & 100.00 & 100.00 \\
\hline
\end{tabular}

Note: * GDP for 2010 is estimated; GDP for 2020 is from the base-case 